\title{
Azerbaycan ve Ermenistan Arasında Bitmeyen Dağlık Karabağ Sorunu
}

\section{Yunus Ekici*}

\section{Özet}

Bu makalede Karabağ sorunun ortaya çıkışı, sorunun çatışmaya dönüşmesi ve barış için uluslar arası kuruluşların girişimleri değerlendirilmiştir. Sorunun ilk olarak tarihsel süreçteki yerine değinilerek, devamında sorunun kuramsal yaklaşımı ele alınmıştır. Karabağ sorunu olarak ifade edilen bu mesele, Azerbaycan topraklarının Ermenistan tarafından işgali sorunudur. Bu sorun, Azerbaycan'ın iç meselesi olarak görülmesi nedeniyle başlangıçta Rusya ve İran soruna müdahale konusunda isteksiz davranmış ancak 1992'den sonra Azerbaycan ve Ermenistan arasındaki devletlerarası bir ihtilafa dönüşmüştür. Dağlık Karabağ sorunu, çatışmaya taraf olan her iki ülkenin ulusal kimliklerinin oluşumunda meydana getirdiği etki yüzünden çözümün önündeki büyük engellerden birini içerisinde barındırmaktadır. Sorunun tarafları olan Ermenistan Cumhuriyeti ile Azerbaycan Cumhuriyeti, SSCB'nin dağılmasının ardından bağımsızlıklarını ilan ederek geç kalan uluslaşma süreçleri içerisinde devlet ve kimlik inşası oluşturma girişimlerini başlatmışlardır.

Anahtar Kelimeler: Dağlık Karabağ, Ermenistan, Azerbaycan, SSCB, Rusya.

\section{Endless Problem of Nagorno-Karabakh Between Azerbaijan and Armenia}

\section{Abstract}

In this article, the emergence of the Karabakh problem, the transformation of the problem into conflict and the initiatives of international organizations for peace have been evaluated. First, the theoretical approach to the problem of continuity has been discussed by referring to its place in the historical process. This issue, which is expressed as the Karabakh conflict, is the Armenian occupation of Azerbaijani lands. At first, Azerbaijan, Russia and Iranian were reluctant to intervene because the problem was regarded as an internal matter, but after 1992, it became an interstate dispute between Azerbaijan and Armenia. The Nagorno-Karabakh conflict is one of the biggest

\footnotetext{
* Dr., Fırat Üniversitesi, Sosyal Bilimler Enstitüsü, Tarih Anabilim Dalı, Elazığ, yunusekici23@hotmail.com. (Makale gönderim tarihi: 12.02.2017, makale kabul tarihi: 08.03.2017)
}

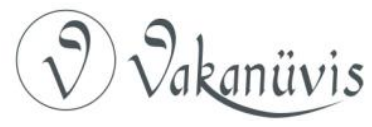


hurdles ahead of the solution because of the impact of the two parties to the conflict on the formation of national identity. The Republic of Armenia and the Republic of Azerbaijan declared their independence after the disintegration of the USSR and initiated initiatives to create state and identity construction in the late nations.

Keywords: Nagorno-Karabakh, Armenia, Azerbaijan, USSR, Russia.

Dağlık Karabağ, Azerbaycan'ın Kür ve Aras ırmakları ile günümüzde Ermenistan sınırları içerisinde bulunan Gökçe Gölü arasındaki dağlık bölge ile bu bölgeye bağlı ovalardan meydana gelen Karabağ bölgesi içinde coğrafi olarak yalnızca 4392 km2'lik bir alanını oluşturan bir bölgedir. ${ }^{1}$ Karadeniz'in doğusundaki Taman yarımadasından Hazar Denizi'nin batısındaki Apşeron yarımadasına kadar uzanan dağlık bölge, Kafkasya olarak isimlendirilmektedir. Kafkasya'nın doğusu Asya kıtasında, batısı ise Avrupa kıtasında yer almaktadır. Karabağ ise Kafkas dağlarının güney doğusunda yer alan bölgede bulunmaktadır. ${ }^{2}$ Karabağ Bölgesi sahip olduğu bu jeopolitik konumu yüzünden yüzyıllarca Osmanlı Devleti ile İran arasında çekişmelere sahne olmuştur. 20. Yüzyıla girilirken Osmanlı Devleti'nin bölgedeki nüfuzu azalmış ve bölgede Rus Çarlığı etkili olmaya başlamıştır. Rusların bölgedeki etkinliği Rus Çarlığının yıkılmasıyla kurulan SSCB döneminde giderek artmıştır. SSCB döneminde Karabağ Bölgesi Kafkaslarda kurulan Ermenistan ve Azerbaycan arasında ciddi bir sorun teşkil etmiş, bunda SSCB'nin sergilemiş olduğu tutum etkili olmuştur. ${ }^{3}$

Ermenistan ile Azerbaycan arasındaki Dağlık Karabağ bölgesi, 1920'de iki ülke arasında bölgenin Ermenistan'a bağlanmasını isteyen Ermeniler ile bunu kabul etmeyen Azeriler arasında ciddi anlamda sorun oluşturmuştur. Bu durum karşısında Bolşevikler bölgeye girerek bölgenin haritasını yeniden çizmişlerdir. Böylece Nahçıvan, Dağlık

1 Ahmet Sapmaz-Gökhan Sarı, “Dağlık Karabağ Sorununda Azerbaycan Tarafından Kuvvet Kullanım Olasılığının Analizi", Güvenlik Stratejileri Dergisi, Yıl:8, Sayı:15, İstanbul, 2012, s.3.

2 Emine Vildan Özyılmaz, "Geçmişten Günümüze Dağlık Karabağ" Gazi Üniversitesi Iktisadi ve Idari Bilimler Fakültesi Dergisi, Cilt:15, Sayı:2, Ankara, 2013, s.193.

${ }^{3}$ Sapmaz, a.g.m., s.3.

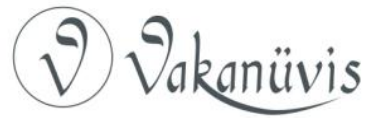


Karabağ ve Zangezur bölgelerini Ermeni yönetimi altına dâhil etmişlerdir. Ancak 1921 yılında Batılı devletlerin sömürgeciliğine karşı Mustafa Kemal Atatürk'ün önderliğinde bir Kurtuluş Savaşı veren Türkiye ile anlaşma yollarını arayan Bolşevikler, Nahçıvan ve Dağlık Karabă̆'ı, tek taraflı olarak Azerbaycan'a bırakmıştır. Böylelikle Türkiye Nahçıvan ile sınır komşusu olmuş ve Azerbaycan ile karadan bağlantı sağlayabilmiştir. ${ }^{4}$

1935 tarihinde Ermeni Komünist Parti Sekreteri, Stalin'den Dağlık Karabağ ve Nahçıvan'ı istemesine rağmen bu talepler SSCB tarafından kabul edilmemiştir. Ermenistan SSCB kurulduğu andan itibaren bu taleplerini sürekli tekrarlamıştır. Genellikle Moskova tarafından bu taleplere olumlu bakılsa da o zamanki dünyanın genel siyasi durumu buna uygun olmadığı için bu talepler reddedilmiştir.

23 Aralık 1947 yılında Stalin tarafından imzalanan bir kararla Ermenistan sınırları dâhilinde tarihi vatanlarından ayrılmak zorunda kalan Karabağ'daki Azeriler, Azerbaycan'ın içlerine doğru göç ettirilmeye zorlandırılmıştır. Bizzat devlet eliyle yürütülen bu zorunlu göçler haricinde baskı ve şiddetlere daha fazla dayanamayan on binlerce kişi de yaşamış olduğu yerleri terk ederek Azerbaycan'a sığınmışlardır. ${ }^{5}$

Dağlık Karabağ sorunu, SSCB'de her iktidar değişikliğinde tekrar ortaya konulmuştur. Ermeni ulusal kimliğinin bir göstergesi şekline bürünen bu soruna ilişkin 1963-1965 Rus lider Kruşçev döneminde, Dağlık Karabağ'ın Ermeni liderleri aracılığıyla Azerbaycan'ın kınanması ve Dağlık Karabağ'ın Ermenistan topraklarına dâhil edilmesi için dilekçeler verilmiştir. Bu istekler Erivan tarafından da belirtilmiş fakat olumlu karşılanmamıştır. ${ }^{6}$

1965 yılında sözde Ermeni soykırımının 50. yılı sebebiyle Erivan'da Türkiye ve Azerbaycan aleyhine gösteriler düzenlenmiş ve büyük çapta

\footnotetext{
${ }^{4}$ Hakan Kantarcl, Kıskaçtaki Bölge Kafkasya, Isparta, 2006, s.48.

${ }^{5}$ Nurettin Latifaci, Dağlık Karabağ Sorunu Bağlamında Türkiye-AzerbaycanErmenistan Ilişkileri, Basılmamış Yüksek Lisans Tezi, Sakarya, 2011, s.41-43.

${ }^{6}$ Demet Ş. Acar-Murat Çemrek, “Kafkasya'nın Kronikleşen Çatışma Alanı: Dağlık Karabağ Özerk Bölgesi", Karadeniz Araştırmaları, Sayı:8, Ankara, 2005, s.125.
}




olmayan çatışmalar yaşanmıştır. Ermenilerin 1970 'li yıllardaki çabaları, Aliyev'in Moskova ile yakın teması sebebiyle sonuçsuz kalmıştır. ${ }^{7}$

1973 yılında Karabağ Komünist Partisi'nin başına getirilen Boris Kevorkov, 15 yıllık görevi sırasında Moskova'nın istediği gibi mevcut durumu korumuştur. Bu dönemde Ermenistan'a dâhil olmak isteyenler Taşnak propagandası yapmakla suçlanmışlardır. ${ }^{8}$

SSCB yönetimi altında uzun yıllar süren siyasi istikrarsızlık, Gorbaçov iktidarı döneminde yeniden su yüzüne çıkmıştır. Dağlık Karabağ sorunu, 1980'lerin ikinci yarısında SSCB'nin dağılmasına giden zaman sürecinde Ermenistan'ın, Azerbaycan'ın Karabağ Bölgesi'nin dağlık kısmına yönelik olan iddiaları yeniden gündeme gelmiştir. ${ }^{9}$

Ermenistan bağımsızlığını kazandıktan sonra en önemli dış politikası Dağlık Karabağ meselesi idi. Dağlık Karabağ meselesi Ermenistan'ın Azerbaycan dışındaki komşularıyla ayrıca $A B D$ ve Rusya ile olan münasebetlerini de etkilemiştir. ${ }^{10}$

\section{Dağlık Karabağ Sorunun SSCB Çıkarları Doğrultusunda Değerlendirilmesi}

1980 'li yılların sonlarında dünyada yaşanan siyasi ve iktisadi gelişmeler sonucunda sosyalizm sistemi çökmeye ve Sovyet yönetimi ülkesindeki egemenliğini yitirmeye başlamıştır. Bu siyasi ortamda, ülkeleri Ruslar tarafından işgal edilmiş olan milletler milli bağımsızlık hareketine girişerek hem Sovyetlerin çöküşünü hızlandırmışlar hem de bağımsızlıklarını elde etmişlerdir. ${ }^{11}$

\footnotetext{
${ }^{7}$ Fulya Oduncu, S.S.C.B.'nin Dağılmasından Günümüze Türkiye'nin Ermenistan ve Azerbaycan Ile Olan Ilişkilerinin Türk Dış Politikasındaki Kafkasya Yaklaşımlarına Etkileri, Basılmamış Yüksek Lisans Tezi, İstanbul, 2011, s.110.

8 Zaur Şiriyev, Avrupa Birliği'nin Bölgesel Çatışmalara Yönelik Politikaları Çerçevesinde Yukarı Karabağ ve Güney Osetya Sorunları, Basılmamış Yüksek Lisans Tezi, Ankara, 2008, s.100.

${ }^{9}$ Kantarcl, a.g.e., s.48.

${ }^{10}$ Kamer Kasım, Soğuk Savaş Sonrası Kafkasya, Ankara, 2009, s.45.

11 Boran Aziz, Mart Faciasından Hocalı'ya Azerbaycan'da Ermenilerin Türk Soykırımı, İstanbul, 2013, s.125.
}

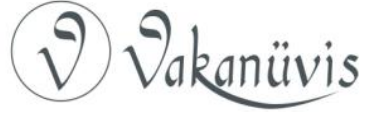


Azerbaycan'da ulusal siyasi mücadelenin başlangıcında kolaylaştırıcı rol oynayan, ülkedeki sosyo-ekonomik durum ve bunun sonucunda merkezi yönetimin uyguladığı "Yeniden Yapılanma ve Açıklık" politikaları dışında kalan bir diğer önemli unsur Karabağ Bölgesi'nin Ermenistan'la birleştirilmesi ile ilgili olarak Ermeni talepleri olmuştur. Karabağ'ın Ermenistan ile birleştirilmesi teklifi ilk kez Kasım 1987'de Gorbaçov'un Fransa ziyareti esnasında yanında bulunan ekonomiden sorumlu danışmanı Abel Aganbekyan'ın verdiği bir demeçle gündeme gelmiştir. ${ }^{12}$

18 Kasım 1987'de Gorbaçov'un ekonomiden sorumlu danışmanı Abel Aganbekyan, Karabağ'ın ekonomik ve siyasi sorunları ile ilgili olarak Fransa'nın L'Humanite gazetesine verdiği demeçte Karabağ'ın Ermenistan'la birleştirilmesi gerektiğini söylemiştir. Aganbekyan'ın bu konuşmasını Avrupa ve Amerika'daki Ermeni gazeteleri manşetten duyurmasına rağmen Moskova, Aganbekyan'ın verdiği demeçle alakalı hiç bir açıklamada bulunmamıştır. ${ }^{13}$

20 Şubat 1988 'de, Azerbaycan'ın yönetiminde olan ve nüfusunun çoğunluğunu Ermenilerin oluşturduğu Dağlık Karabağ Özerk Bölgesi ve Ermenistan, alınan siyasi bir karar ile sallanmıştır. Dağlık Karabağ'ın başkenti Stepanakert'in şehir meclisi, Ermenistan-Azerbaycan sınırının değiştirilmesi ve Karabağ'ın Ermenistan'ın bir parçası haline getirilmesi hususunda Moskova'ya bir teklif götürme kararı almıştır. Karabağ'ın bu arzusu Erivan'da kalabalık toplantılar ve gösterilerle desteklenmiştir. Bu gösteriler Sovyet bloğunda gerçekleşecek halk hareketlerinin ilk örneğini teşkil etmiştir. 1989 yılında Ermenistan Yüksek Sovyet'inde çıkan bir tartışmada Ermeni Ulusal Hareketi'ne göre Ermenistan'ın bağımsızlığını kazanmış bir devlet olması için geleneksel düşünce tarzını bırakması gerektiği vurgulanmıştır. ${ }^{14}$

13 Şubat 1988 tarihinde Azerbaycan'a bağlı bulunan Dağlık Karabağ Özerk Bölgesi'ndeki Ermeni halkın bölgedeki idari kurumlara

${ }^{12}$ Cavid Veliev- Araz Aslanlı, Güney Kafkasya; Toprak Bütünlügü, Jeopolitik Mücadeleler ve Enerji, Ankara, 2011, s.16-17

${ }^{13}$ Firat Karabayram, Güney Kafkasya Jeopolitiğinde Rusya Gerçeği, İstanbul, 2011, s.78.

${ }^{14}$ Karabayram, a.g.e., s.67.

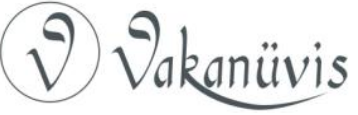


Ermenistan Sovyet Sosyalist Cumhuriyeti bayrağını asması, bölgedeki Azerilere baskı yapması ve şubat ayında Dağlık Karabağ Özerk Bölgesi Yönetim Kurulu'nun olağanüstü bir toplantı düzenleyerek özerk bölgenin Ermenistan ile birleştirildiğine ilişkin önemli bir karar alması nedeniyle Azerbaycan'da geniş çaplı toplumsal tepkiler görülmeye başlanmıştır. ${ }^{15}$

12 Temmuz 1988'de DKÖB yerel meclisi, Azerbaycan'dan ayrılma kararı almış ancak bir sonraki gün toplanan Azerbaycan Yüksek Sovyet'i Başkanlık Divanı yerel meclisin bu kararını geçersiz kabul etmiştir. Yaşanan bu gelişmelerden sonra 18 Temmuz'da toplanan SSCB Yüksek Sovyet'i Başkanlık Divanı her iki cumhuriyetin kararlarını istişare ederek kararını vermiştir. Neticede Gorbaçov, Karabağ sınırlarının değiştirilemeyeceğini duyurmuştur. Alınan bu karar Ermenilerin tepki göstermesine neden olmuş ve Ermeniler, Azerbaycan'dan ayrılma yönündeki taleplerini hızlandırmıştır.

Azeriler ve Ermeniler arasındaki çatışmaların bitmemesi üzerine Azerbaycan'ın Gence şehrinde ve Nahçıvan'da 24 Kasım 1988'de örfi idare ilân edilmiş ve üç gün sonra bu şehir ve bölgenin parti başkanları görevden alınarak askeri birlikler bu bölgelerden Ermenileri tahliye etmeye başlamışlardır. Bu olaydan sonra on binlerce Azeri ve Ermeni, Azerbaycan ve Ermenistan'ı terk etmiştir. Moskova basınında çıkan haberlere göre olaylar sırasında 87 kişinin öldüğü 1500 kişinin de yaralandığı, 158.000 Ermeni halkının Azerbaycan'dan ve 141.000 Azerinin Ermenistan'dan ayrıldığı, 15.855 silahın da ele geçirildiği bildirilmiştir ${ }^{16}$

1988 Dağlık-Karabağ Savaşında hayatını kaybedenler ile ilgili net resmi rakamlar bulunmamakla beraber 20.000 'den fazla asker ve sivilin bu savaşta öldüğü tahmin edilmektedir. $1988^{\prime}$ den beri süren çatışmalar iki tarafta da yeni mülteciler ve ülke içinde yerinden edilmiş kişiler yaratmıştır. ${ }^{17}$

\footnotetext{
${ }^{15}$ Veliev, a.g.e, s.16-17.

16 Duhan Kalkan, Güney Kafkasya bölgesi'ndeki Etnik Çatışma Alanları, Basılmamış Yüksek Lisans Tezi, Konya, 2010, s.38.

17 Aybars Görgülü, "Türkiye-Ermenistan İlişkileri ve Dağlık Karabağ Sorunu", Yeni Türkiye Dergisi, Sayı:60, Ankara, 2014, s.3.
}

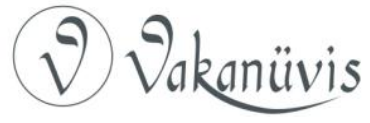


Merkezi yönetimin Ermeni taraftarı tutumuyla Azerbaycan'daki komünist yönetimin Karabağ'daki olaylara gerekli tepkiyi gösterememesi, Azerbaycan toplumunda siyasi mücadeleye yönelimi artırmış ve Karabağ sorununun çözümünde ulusal mücadelenin başlaması gerektiği inancını düşündüren önemli bir etken olmuştur. Gerçekten de komünist yönetime karşı halkın net bir biçimde tepkisini ortaya koyduğu ilk gösteri Karabağ olayları sonucunda yapılmış ve bu gösteride genellikle Karabağ'ın savunulmasına ilişkin sloganlar dikkat çekmiştir. Bu şekilde gündeme gelen Karabağ hassasiyeti ve savunmacılığı sonrasında ülkede yüz binlerce kişinin katıldığı ulusal mücadele mitingleri düzenlenmiştir. Bu durum Karabağ sorununa yeterince tepki göstermeyen yerel komünist yöneticilere karşı muhalefetin ortaya çıkışının ve örgütsel bir harekete dönüşümünün temelini atmıştır. ${ }^{18}$

Uluslararası hukuk açısından Dağlık Karabağ çatışması dikkatle incelendiğinde, Ermenistan'ın tarihi kanıtları öne sürerek toprak talebinde bulunması kabul görmemekte ve Azerbaycan'ın tutumu desteklenmektedir. Ermenilerin self-determinasyon ilkesi doğrultusunda hareket ettiklerine dair tezleri de uluslararası hukuk tarafından uygun görülmemektedir.

Ermenistan bu zaman sürecinde Türkiye ile ilişkilerini gerginleştirmeyen bir politika izlemiş hatta Türkiye'nin Dağlık Karabağ sorununda çözüm süreci içerisinde bulunmasını isteyerek arabuluculuk yapmasını teklif etmiştir. Türkiye, bazı kesimlerce Azerbaycan taraftarı bir politika izlediği kabul edilse de dış politikasındaki kararsızığını yenerek tarafsız kalmaya çalışmış ve arabuluculuk çalışmalarında bulunmuştur. ${ }^{19}$

SSCB yönetimi, bitmek bilmeyen olaylar karşısında Azerbaycan ve Ermenistan'a karşı sert bir tavır sergilemeye başlamıştır. Ermenistan'da gösteri düzenleyen Karabağ komitesi mensupları hemen tutuklanmış ve gece sokağa çıkma yasağı getirilmiştir. Bunun yanı sıra Ermenistan ve Azerbaycan Komünist Partilerinde ve yerel hükümetlerde önemli değişiklikler söz konusu olmuştur. 28 Ocak 1989 tarihinde Azerbaycan

\footnotetext{
${ }^{18}$ Veliev, a.g.e., s.17.

${ }^{19}$ Acar, a.g.m., s.127.
}

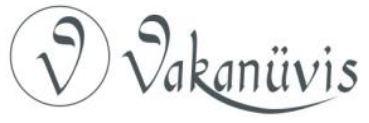


Başbakanı Hasan Seyitov'un sağlık nedeniyle görevine son verilmiş yerine Ayaz Mutalibov getirilmiştir. Karabağ'da ise Komünist Partisi Birinci Sekreteri Genrik Pogosyan da sağlık nedeniyle görevinden alınmıştır. 12 Ocak 1989'da Sovyetler Birliği Yüksek Sovyet'i DKÖB'nin yönetimini Azerbaycan'dan alarak yönetimini Özel Karabağ Komitesine bırakarak Moskova'ya bağlamıştır. ${ }^{20}$

\section{Dağlık Karabağ Sorununda Politik Çözüm Arayışları ve Çözümsüzlük}

Dağlık Karabağ günümüz itibariyle askeri manada savunmaya müsait bir sınıra ve eski Sovyet Karabağ'ın idari sınırı süresince devam eden bir ara bölgeye sahiptir. Karabă̆'ı Ermenistan'a bağlayan ara bölge ve Laçin koridorundan dolayı Dağlık Karabağ ve Azerbaycan orduları arasındaki potansiyel temas alanı büyük oranda azalmaktadır. Kuzeyde geçilmesi çok zor bir dağ sırası ve güneyde de İran ile sınır bulunmaktadır. Sınııın kısa olması Ermenistan'ın Dağlık Karabağ'da Azerbaycan'ın çok daha etkili kuvvetleri tarafından gerçekleşecek herhangi bir saldırıyı püskürtebilmesini kolaylaştırmaktadır. Dağlık Karabağ, ara bölgeyi oluşturan bölgelerden askerlerini çekerse savunmasını zayıflatacağından ve Bakü'de askeri bir çözüme yönelik yeni umutların ortaya çıkmasından korkmaktadır. Bu algı Azerbaycan'ın askeri bütçe oluşturması ve yeni savaş tehditleri ortaya atmasıyla iyice güçlenmektedir. Karşılıklı imtiyazlara dayanan ve Dağlık Karabağ’ın nihai durumunu tanımlayan bir barış antlaşması imzalanmadığı sürece Dağlık Karabağ savunmasını azaltmaya hazırlıklı değildir. Hatta güçlendirilmiş sınırlar ve uluslararası toplumun askeri çözüme ödün vermeden karşı çıkması bölgede yeniden silahlı çatışma çıkmasını engelleyen başlıca önlemler olmaya devam etmektedir. ${ }^{21}$

1988 yılı sonlarına doğru başgösteren çatışmalar 1989 yılında daha çok yoğunlaşmış ve 1990'ların ilk başlarında şiddetini artırarak Ermenistan ve Azerbaycan arasında ilan edilmemiş bir savaşa dönüşmüştür. Çatışmanın başladığı ilk yıllarda sorun uluslararası kamuoyu tarafından SSCB'nin iç meselesi olarak düşünülmüş ve çözüm

${ }^{20}$ Kalkan, a.g.t., s.39.

21 Aybars Görgülü, Alexander Iskandaryan, Sergey Mınasyan, TürkiyeErmenistan Diyalog Serisi: Yakınlaşma Sürecini Incelemek, İstanbul, 2010, s.16.

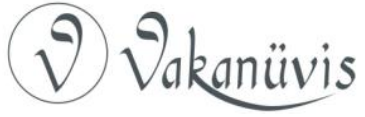


için girişimler de daha çok Moskova tarafından yapılmıştır. Dağlık Karabağ'da inisiyatifi kaybetmek istemeyen Moskova soruna BDT çerçevesinde çözüm aramıştır. ${ }^{22}$

Türkiye, Kafkaslarda genel itibariyle bir bölgesel barış veya çözüm oluşturabilecek bir dış politika izlemeye çalışmıştır. Türkiye AGiT Minsk $^{23}$ grubundan, Dağlık Karabağ'ın resmi statüsünün Azerbaycan içinde özerk bir bölge olarak tanınması yolunda güvence almıştı ve meşruluğun şiddet kullanarak bozulmasına izin verilmemesini talep etmiştir. Bu arada Türkiye, Ermenistan'a işgal ettiği Azeri kasaba ve köylerinden ve Laçin'den geri çekilmesi hususunda da ısrar etmiştir. Siyasal ilişkilerin kurulması için Ermenistan'la bazı görüşmeler yapmıştır. Türkiye bir yandan bütün Sovyet Cumhuriyetleriyle iki yanlı ilişkilerini geliştirmeye çalışmakta diğer taraftan bu ülkeler arasındaki iki taraflı anlaşmazlıklarda taraf olmamaya çalışmaktadır. ${ }^{24}$

Dağıık Karabağ sorunu, Türkiye'nin Ermenistan kaynaklı yeni güvenlik tehdidiyle karşı karşıya kalması ve Sovyetler Birliği sonrası Kafkasya'ya ve Orta Asya'ya siyasi, ekonomik, kültürel ve askeri açılımlar yapma gayretlerini ciddi anlamda etkileyen bir öneme sahip olmuştur. Sovyetler Birliği sonrası dönemde bölge içi ve bölge dışı devletlerin (özellikle Rusya, İran ve ABD) bölgeye yönelik çıkarlarında değişiklik yaşanması, Dağlık Karabağ sorununu Kafkaslar ve oradan Orta Asya'ya uzanan geniş bir coğrafyada jeopolitik mücadelenin odak noktasına yerleştirmektedir.

22 Adalet Ibadov, Azerbaycan Dış Politikasında Dağlık Karabağ Sorunu ve Ermeni Sorunu: Çözümler, Öneriler, Basılmamış Doktora Tezi, İzmir, 2007, s.143.

${ }^{23}$ AGiT'in 1992'deki ateşkesten hemen önce oluşturduğu inisiyatif, Minsk Grubu olarak adlandırılmaktadır. Söz konusu grup; Türkiye, Rusya, Fransa, ABD, İtalya, Almanya, Beyaz Rusya, İsveç, Finlandiya, Portekiz, Hollanda, Ermenistan ve Azerbaycan'dan temsilcileri içermektedir. Grup, bu temsilciler vasıtasıyla sorunun çözümü için müzakereleri yürütmektedir. Ermenistan, Azerbaycan ve Karabağ'dan temsilcilerle buluşan Minsk Grubu, ilk on yılda sorunun çözümüne yönelik herhangi bir değişiklik olmadan süreci devam ettirmiştir. (Uğur Yasin Asal, “Dağlık Karabağ Sorunu'nun Çatışma Çözümü Perspektifinden Analizi" Asya'da Güvenlik Sorunları ve Yansımaları, İstanbul, 2013, s.62.)

${ }^{24}$ ibadov , a.g.t., 138-139.

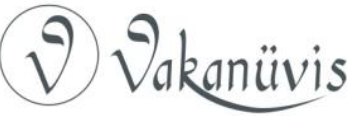


Türkiye Azerbaycan bağımsızlığını ilan ettikten sonra bu ülke ile başta eğitim konusunda olmak üzere teknik ve kültürel alanlarda ilişkilerini canlı tutma çabası içine girmiştir. Bu durum ikili ilişkileri geliştirme isteğinin yanında Azerbaycan'ı Rusya'nın etkisinden kurtarma düşüncesinden de ileri gelmiştir. ${ }^{25}$

1990 yılı Ocak ayında Azeriler ve Ermeniler arasında sıcak çatışmalar vuku bulmuştur. Bu bağlamda, 12 Ocak 1990'da Ermenilerin bölgedeki iki Türk yerleşim birimine ateş açmaları sonucunda 12 kişi ölmüş, 22 kişi Ermenilerce esir alınmıştır. 13 Ocak 1990'da Bakü'de Ermeniler tarafından gerçekleştirilen bir saldırıda bir Azeri ölmüş bir Azeri de ağır yaralanmıştır iki Azerbaycanlıya baltayla saldırılması sonucu birisi ölmüş, diğeri ise ağır yaralanmıştır. Bu haberin o sırada gerçekleştirilen büyük bir mitinge ulaşması sonucu karşı saldırı düzenlenmiş ve bu saldırı esnasında çoğunluğu Ermeni olan toplam 34 kişi hayatını kaybetmiştir. Moskova yönetimi, yaşanan gelişmelerin tehlike arz ettiğini gerekçe göstererek, Bakü'de ve Azerbaycan'ın birçok bölgesinde (DKÖB dâhil) olağanüstü hal ilan etmiştir. 20 Ocak 1990 tarihinde 20.000 askerden oluşan Kızıl Ordu birlikleri havadan, karadan ve denizden Bakü'ye saldırmış, operasyonu yöneten Savunma Bakanı Yazov ve İçişleri Bakanı Bakatin yerine, yapılan operasyon sonucu birkaç yüz insanın hayatını kaybettiğini ve 700 kişinin de yaralandığını duyurmuştur.

Bu dönemde Karabağ sorununu çözüme kavuşturmak için Azerbaycan'da Teşkilat Komitesi kurulmuş ve Azerbaycan Komünist Partisi'nde önemli mevkide bulunan V. Polyaniçko bu komiteye başkan olarak atanmıştır. Teşkilat Komitesi başlangıçta sorunu çözüme kavuşturmak için uğraşmışsa da daha sonraki süreçte etkisini kaybetmiştir. 17 Mart 1991 yılında yapılan ve SSCB'ye bağlı yönetimlerde birliğin devamını sağlamak amacıyla şaibeli bir halk oylaması yapılmıştır. 1991 yılının 19-21 Ağustos'ta ise Moskova'da hükümet darbesi gerçekleştirilmişti. Bu darbe Azerbaycan'ın bağımsızlığını ilan etmesini kaçınılmaz hale getirirken Ermenistan'da da yeniden başkanlık seçiminin yapılmasına neden olmuştur. 16 Ekim

${ }^{25}$ Güner Özkan, “Türk Dış Politikası (1919-2008)", "Kafkaslar ile ilişkiler", Ankara, 2008, s.835.

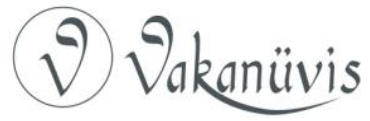


1991'de yapılan seçimlerle Levon Ter- Petrosyan oyların \%83'ünü alarak büyük zafer elde etmiştir. ${ }^{26}$

Levon Ter Petrosyan iktidarı döneminde yapılan görüşmelerde Azerbaycan tarafı ile kademeli bir çözüme yönelik çerçeve çizilmiştir. Yapılan görüşmelerde, Ermenistan'ın işgal altında bulundurduğu yedi bölgenin önemli bir kısmını boşaltması, Türkiye ve Azerbaycan ile kapalı olan Ermenistan sınırının yeniden açılması gündeme gelmiştir. Bu gelişmelerden sonra Dağlık Karabağ Özerk Bölgesinin statüsünün de tartışma konusu olmasına karar verilmiştir. ${ }^{27}$

Ermenistan devlet başkanı Levon-Ter Petrosyan uzun süren barış görüşmeleri sonrasında Aşamalı Çözüm Planı ile birlikte olumlu tutum içerisinde görünmüştür. Ermenistan devlet başkanının olumlu tavrı çözüm için umutları arttırmıştı. Ancak Levon-Ter Petrosyan ülke içindeki muhalefetin ve Dağlık Karabağ Ermeni çetelerinin baskısı altında geri adım atmak zorunda kalmıştır. Uzlaşmaz iç muhalefetin ve dışarıdaki diaspora Ermenilerinin baskılarına daha fazla dayanamayan Petrosyan devlet başkanlığından istifa etmek zorunda kalmıştır. Petrosyan'ın istifa etmesi bir anlamda Dağlık Karabağ sorununun çözümünde büyük oranda tekrar başa dönmek anlamına geliyordu. ${ }^{28}$

1991'de Azerbaycan, bağımsız olma yolunda önemli adımlar atarken Karabağ Ermenileri de kendilerini "Artsak Ermeni Cumhuriyeti" olarak ilan etmiştir. Azerbaycan parlamentosu ise böyle bir durumun anayasaya aykırı olduğu gerekçesiyle karara sert tepki göstermişti. Ermenilerin, Şaumyan bölgesindeki köylere saldırıda bulunmasıyla Yeltsin ve Kazakistan Devlet başkanı Nazarbayev girişimleri sonucu sorunun çözülmeye çalışılması için Kafkasya'da Jeleznovodsk kentinde, 24 Eylül 1991 tarihinde iki ülke arasında anlaşma sağlanmıştır. Yapılan bu anlaşmaya göre ateşkes olacak, Ermenistan; Karabağ'ın Azerbaycan'a ait olduğunu kabul edecek, bölge halkının kendisini yönetmesi için bazı imkânlar sağlanacaktır. 20 Kasım

\footnotetext{
${ }^{26}$ Yunus Ekici, Ikinci Dünya Savaşından Bağımsızlığına Kadar Gürcistan (19391991), Basılmamış Doktora Tezi, Elazığ, 2017, s.158-159.

27 M.Turgut Demirtepe, Dağlık Karabağ Sorunu: Dar Alanda Büyük Oyun, Ankara, 2011, s.24.

${ }^{28}$ ibadov, a.g.t., s.164.
}

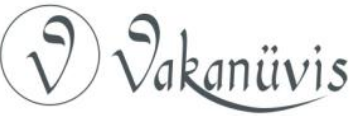


1991 tarihinde ise Azerbaycan'ın ateşkes kararına uyulmadığını kanıtlamak amacıyla davet ettiği Rus ve Kazak gözlemcilerin içinde bulunduğu helikopter, Ermeniler tarafından düşürülmüştür. Bu olay Azerbaycan yönetimini birtakım tedbirler almaya sevk etti. Bu tedbirlerin ilki Ermenistan'a ulaşan demir yolunun kapatılmasıdır. Ayrıca Azerbaycan Yüksek Sovyet'i 26 Kasım 1991 tarihli toplantısında Dağlık Karabağ Özerk Bölgesi'nin mevcut statüsünü kaldırarak onu oluşturan ilçeleri direkt Bakü'ye bağladı. Ancak gelişen bu durum barış görüşmelerinden sonuç alınamamasına yol açmıştır. ${ }^{29}$ Yaşanan bu gelişmeler Dağlık Karabă̆'ın gelecekteki statüsünün belirlenmesi ile ilgili olarak Ermenistan ve Azerbaycan'ın her zamankinden çok daha uzakta olduğunu ortaya koymaktadır. ${ }^{30}$

Karabağ sorununa çözüm bulmak maksadıyla 1992'de kurulan Avrupa Güvenlik ve İşbirliği Teşkilatı (AGIT) Minsk Grubu da sorunun çözümü için somut bir sonuç alamamıştır. Azerbaycan ve Ermenistan kamuoylarının farklı beklentileri sorunun çözülmemesindeki önemli sebeplerinden biridir. 1994 yılında AGiT Minsk Grubu eş başkanlığına $A B D$, Rusya ve Fransa getirilmiştir. Beyaz Rusya, Almanya, İtalya, Portekiz, Hollanda, İsveç, Finlandiya ve Türkiye ile sorunun tarafları olan Azerbaycan ve Ermenistan, Minsk Grubu'nun diğer üyeleridir. Türkiye'nin Minsk Grubu'ndaki eş başkanlığını Azerbaycan desteklerken, Ermenistan buna karşı çıkmıştır. Minsk Grubu 1992'den beri Ermenistan ve Azerbaycan arasındaki barış sürecini yönetmektedir. BM de sorunun çözüme kavuşmasına yönelik birçok girişimde bulunmuştur. ${ }^{31}$

BM Genel Sekreteri Butros Gali, 1994 yılında Genel Kurul'a sunduğu raporda Azerbaycan'daki durumun son derece kötü olduğunu

29 Mustafa Gökçe, "Yukarı Karabağ Sorunu ve Türkiye-Ermenistan İlişkileri Üzerine Bir Değerlendirme", Turkish Studies Dergisi, Sayı:6/1, Ankara, Kış 2011, s.1116.

30 Ohannes Geukjıan, Ethnicity, Nationalism and Conflict in the South Caucasus: Nagorno-Karabakh and the Legacy of Soviet Nationalities Policy, New York, 2012, s.209.

31 Ümit Nazmi Hazır, “Azerbaycan ve İslam Dünyasının Kanayan Yarası: 'Karabağ'”, IHH Insani ve Sosyal Araştırmalar Merkezi, İstanbul, Şubat 2016, s.6.

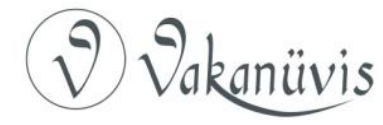


bildirmiştir. Savaşın etkisinin çatışmalardan uzak bölgelerde hissedildiğini, sağlık ve sosyal hizmetlerin aksadığını, hayat seviyesinin çok düştüğünü kaydetmiştir. Yaşanan çatışmalar yüzünden ülkenin altyapısının hasar gördüğünü ve tarım alanlarının kullanılamadığını da belirmiştir. $^{32}$

Günümüzde Bakü, toprak bütünlüğü konusunda kararlılığını korurken; Erivan, milletlerin self determinasyon hakkına dikkati çekmektedir. Azerbaycan'ın pozisyonunun temel dayanak noktası, Dağlık Karabağ'ın Azerbaycan'ın bir parçası olmasıdır. Bakü, bu bağlamda sözde Dağlık Karabağ yönetiminin çözüme taraf olmasına da sıcak bakmamaktadır. ${ }^{33}$

\section{Sonuç}

Dağlık Karabağ çatışması Sovyetler Birliği'nin dağılmasından önce başlayan ve birliğin dağılmasından sonra bağımsız devletlerarası çatışmaya dönüşen, Soğuk Savaş dönemi sonrası en yıkıcı bölgesel savaşlardan biri olarak karşımıza çıkmaktadır. Savaşta 1 milyon Azerbaycan vatandaşı mülteci durumuna düşmüş ve Azerbaycan topraklarının \% 20 si Ermeni işgaline uğramıştır.

Azerbaycan ve Ermenistan'ın bağımsızlıklarını kazanmaları ve Dağlık Karabağ'daki mevcut durumun kendisini "Dağlık Karabağ Cumhuriyeti" olarak ifade etmesinin ardından daha önce Sovyetler Birliği'ne ait iç sorun olan Karabağ, uluslararası bir sorun haline gelmiştir.

Dağlık Karabağ sorunu, Kafkasya'da siyasi istikrar, ekonomik büyüme ve bölgesel işbirliğinin gerçekleştirilmesini engelleyen önemli bir sorun olarak görülmektedir. Türkiye, Ermenistan'ın iyi komşuluk ilişkileriyle uyumluluk gösteren politikalar benimsemesi halinde bu ülke ile ilişkilerini normal bir seyire sokma arzusu içindedir. Ancak Ermenistan'ın uluslararası hukukun temel prensiplerini ve BM Güvenlik Konseyi kararlarına uymaması ve Türkiye'ye karşı Ermeni diasporasıyla birlikte sergilediği düşmanca tavır, iki ülke ilişkilerini ipotek altına almaktadır. Ayrıca Türkiye, Ermenistan'ın bu tavrının ülkemizde

${ }^{32}$ Milliyet Gazetesi, 29.10.1994, s.19.
${ }^{33}$ Ahmet Sapmaz-Gökhan Sarı, a.g.m., s.7.

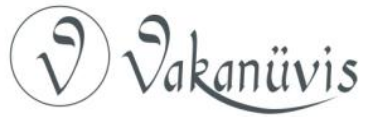


diplomatik ilişkiler kurması yönünde engel oluşturduğu kanaatine varmasını da ümit etmektedir.

Karabağ sorunu geçmişte olduğu gibi bugün de Güney Kafkasya'nın merkezinde bölge güvenliğini tehdit eden bir durumdadır. Sorun her ne kadar bir Azeri-Ermeni çatışması olarak görünse de sorunun temelinde bir Hristiyan-Müslüman çatışması olduğu algısı yüksektir. Günümüzde taraflar kendi fikirlerini, küresel güçlerin bölgesel menfaatleriyle özdeşleştirerek kazançlı çıkmaya çalışmaktadır. Buna karşın uluslararası kamuoyu sorunun çözümü için gereken siyasi inisiyatifi yerine getirememektedir. Bu durumdan yarar sağlamaya çalışan Ermenistan, Dağılık Karabağ'ı yavaş yavaş bir devlet gibi şekillendirerek ayrılma noktasına getirmiştir. Bu doğrultuda sorun, Azerbaycan için hiç de iyiye doğru gitmeyen bir noktaya doğru gitmektedir. Azerbaycan liderlerinin açıklamalarına bakıldığında ise Azerilerin intihar olarak değerlendirilebilecek adımlar atmaktan geri kalmayacağı açık bir şekilde görünmektedir. Dolayısıyla tüm Kafkasya'yı içine alabilecek bir çatışma alanı kaçınılmaz görünmektedir. Dağlık Karabağ meselesinde çözüm odaklı bir antlaşma sağlanacaksa Ermenilerin işgal altında tuttuğu toprakların işgalini sonlandırması gerekmektedir.

Netice itibariyle günümüzde Azerbaycan-Türkiye-Ermenistan arasında devam eden yaklaşık iki asırlık sorunun adı olan "Ermeni Meselesi" ve "Karabağ Sorunu"nun, başta Ruslar olmak üzere emperyalist güçler tarafından oluşturulmuş yapay bir sorun olduğu görülmektedir. Kanaatimize göre Ermenistan ve Azerbaycan arasındaki Dağlık Karabağ sorunu uzun süreli ateşkes ve yer yer çatışmalar halinde devam edecektir.

\section{Kaynakça}

Acar Demet Şefika - Çemrek Murat, "Kafkasya'nın Kronikleşen Çatışma Alanı: Dağlık Karabağ Özerk Bölgesi”, Karadeniz Araştırmaları Dergisi, Sayı:5, Ankara, 2005.

Aziz, Boran, Mart Faciasından Hocalı'ya Azerbaycan'da Ermenilerin Türk Soykırımı, İstanbul, 2013.

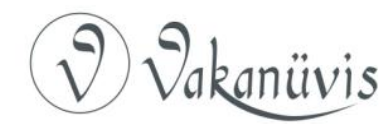


Demirtepe, M.Turgut, Dağlık Karabağ Sorunu: Dar Alanda Büyük Oyun, Ankara, 2011.

EKici, Yunus, ikinci Dünya Savaşından Bağımsızığına Kadar Gürcistan (1939-1991), Basılmamış Doktora Tezi, Elazığ, 2017.

Geukjian, Ohannes, Ethnicity, Nationalism and Conflict in the South Caucasus: Nagorno-Karabakh and the Legacy of Soviet Nationalities Policy, New York, 2012.

Gökçe, Mustafa, "Yukarı Karabağ Sorunu ve Türkiye-Ermenistan Iliş̧ileri Üzerine Bir Değerlendirme", Turkish Studies Dergisi, Sayı:6/1, Ankara, Kış 2011.

Görgülü, Aybars, "Türkiye-Ermenistan İlişkileri ve Dağlık Karabağ Sorunu", Yeni Türkiye Dergisi, Sayı:60, Ankara, 2014.

Görgülü, Aybars-Iskandaryan,Alexander-Mınasyan,Sergey, Türkiye-Ermenistan Diyalog Serisi: Yakınlaşma Sürecini Incelemek, İstanbul, 2010, s.16.

Hazır, Ümit Nazmi, "Azerbaycan ve İslam Dünyasının Kanayan Yarası: 'Karabağ'”, iHH insani ve Sosyal Araştırmalar Merkezi, İstanbul, Şubat 2016.

IBADOV, Adalet, Azerbaycan Dış Politikasında Dağlık Karabağ Sorunu ve Ermeni Sorunu: Çözümler, Öneriler, Basılmamış Doktora Tezi, İzmir, 2007.

Kalkan, Duhan, Güney Kafkasya Bölgesi'ndeki Etnik Çatışma Alanları, Basılmamış Yüksek Lisans Tezi, Konya, 2010.

Kantarcı, Hakan, Kıskaçtaki Bölge Kafkasya, Isparta, 2006.

Karabayram, Fırat, Güney Kafkasya Jeopolitiğinde Rusya Gerçeği, İstanbul, 2011.

Kasım, Kamer, Soğuk Savaş Sonrası Kafkasya, Ankara, 2009.

Latifaci, Nurettin, Dağılk Karabağ Sorunu Bağlamında Türkiye-AzerbaycanErmenistan Iliş̧kileri, Basılmamış Yüksek Lisans Tezi, Sakarya, 2011.

Milliyet Gazetesi, 29.10.1994.

Oduncu, Fulya, S.S.C.B.'nin Dağılmasından Günümüze Türkiye'nin Ermenistan ve Azerbaycan ile Olan Iilişkilerinin Türk Dış Politikasındaki Kafkasya Yaklaşımlarına Etkileri, Basılmamış Yüksek Lisans Tezi, İstanbul, 2011.

Özkan, Güner, "Türk Dış Politikası (1919-2008)", "Kafkaslar ile ilişkiler", Ankara, 2008.

Özyılmaz, Emine Vildan, "Geçmişten Günümüze Dağlık Karabağ" Gazi Üniversitesi iktisadi ve Idari Bilimler Fakültesi Dergisi, Cilt:15, Sayı:2, Ankara, 2013.

Sapmaz Ahmet - Sarı Gökhan, "Dağlık Karabağ Sorununda Azerbaycan Tarafından Kuvvet Kullanım Olasılı̆ıının Analizi" Güvenlik Stratejileri Dergisi, Yıl:8, Sayı:15, İstanbul, 2012.

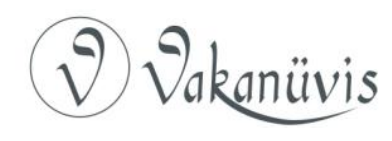


Şiriyev, Zaur, Avrupa Birliği'nin Bölgesel Çatışmalara Yönelik Politikaları Çerçevesinde Yukarı Karabağ ve Güney Osetya Sorunları, Basılmamış Yüksek Lisans Tezi, Ankara, 2008.

Veliev Cavid- Aslanlı Araz, Güney Kafkasya; Toprak Bütünlüğü, Jeopolitik Mücadeleler ve Enerji, Ankara, 2011. 